\title{
Professional and Personal Physical Therapist Development through Service Learning in Collaboration with a Prisoner Reinsertion Program: A Qualitative Study
}

\author{
Isabel Rodríguez-Costa ${ }^{1}$ (), Ma Dolores González-Rivera ${ }^{2}$, Catherine Ortega ${ }^{3}$, \\ Joana-Marina Llabrés-Mateu ${ }^{4}$, María Blanco-Morales ${ }^{5}$ (D), Vanesa Abuín-Porras ${ }^{5, *(D)}$ \\ and Belén Díaz-Pulido ${ }^{1}$ (D) \\ 1 Nursing and Physiotherapy Department, Alcala University, 28805 Alcalá de Henares, Spain; \\ isabel.rodriguezc@uah.es (I.R.-C.); belen.diazp@uah.es (B.D.-P.) \\ 2 Biomedical Sciences Department, Alcala University, 28805 Alcalá de Henares, Spain; \\ marilin.gonzalez@uah.es \\ 3 Physical Therapy Department, Health Science Center, San Antonio, Texas University, \\ San Antonio, TX 78229, USA; ortegac2@uthscsa.edu \\ 4 Consellería d'Educació, Universitat I Recerca del Govern Illes Balears, 07009 Palma, Spain; \\ joanamarinallabres@gmail.com \\ 5 Faculty of Sport Science, Universidad Europea de Madrid, 28670 Madrid, Spain; \\ maria.blanco@universidadeuropea.es \\ * Correspondence: vanesa.abuin@universidadeuropea.es
}

Received: 20 November 2020; Accepted: 9 December 2020; Published: 12 December 2020

check for updates

\begin{abstract}
There is a great concern whether Physical Therapy students upon completion of their educational program are ready and equipped with the requisite skills to construct and implement a successful patient intervention with culturally diverse groups. The purpose of this study is to describe the professional and personal physical therapist development of Physical Therapy students after participating in Solidarity Activities in Collaboration with a Prisoner reinsertion program as a service-learning course. A qualitative approach was used. A convenience sample of twenty physical therapy students doing service learning and one teaching professor were included. Student diaries were analyzed. Semi-structured interviews were done to explore five students' and the professor's judgements. Internal and external observations and filling out structure field-notes were also used as data triangulation in order to build the conceptual model. The main findings include that the application of knowledge and practice of skills in different environments are the most important skills attained with this service learning. Five key themes emerged from the data analysis, namely: application of knowledge, adaptation to different environments, improving communication with patients, assisting people and providing treatment with self-confidence. A recommendation is that Physical Therapy programs include workplace practice in different environments to enhance the development of professionalism among students.
\end{abstract}

Keywords: development; physical therapy student; prisoners; service learning

\section{Introduction}

Healthcare professionals need to be prepared to confront a challenging world and provide quality patient interventions. Educational formation is the first step to attaining this goal. The need to develop personal and professional skills is well-recognized as enabling future physical therapists to function 
efficiently [1]. Nowadays, managing stress and enhancing resilience are important considerations for becoming successful in physical therapy interventions [2].

To prepare students for the interactive world in multicultural environments it is important to practice in varied environments [3]. One of the special groups that physiotherapists treat, and which students could practice with, is the prisoner population. This is the group of interest that would participate in a reinsertion program. Because it is vital for this community to learn healthy physical exercise habits, the prisoner environment is for physiotherapists a new emerging workplace. In this context, students can apply their theoretical knowledge [4] and practice their communication skills [5]. Physical therapists could expand their profession, because professions evolve as a result of their interrelations with others [6]. The prison location is another place where a physical therapist could be considered a primary care practitioner [7].

In this framework emerges "Solidarity Activities in Collaboration with a Prisoner Reinsertion Program" (SACP) as a service-learning course in a Spanish Physical Therapy program. This course was created with the objective of giving physical therapy care to special groups who in other conditions would not have access to this care [8]. One of these under-served groups are prisoners who participate in a community reinsertion program thorough sports, called "Running Makes You Free." Within the course, physical therapy students create and deliver educational sessions to inmates once a month. The information presented includes different physical therapy techniques and healthy sports habits. This course was created to provide students extra clinical practice in varied environments [9].

Physical therapy education requires applied learning as a central part of the formation. This kind of learning includes learning skills in the workplace [10]. It is known that experiential learning is the best manner to develop clinical reasoning expertise [11]. Experiential learning facilitates socialization in a practice community, it is collaborative work [12] and gives the opportunities for students to apply theoretical knowledge, to integrate it into practical settings and to build their own learning process [13-15]. It is a form of interactive learning and was added to this curriculum to enhance educational development as well as translational learning for this group of physical therapy students [16].

In situ experience for students outside the university facilitates personal grown, active engagement and promotes motivation and interest for learning $[17,18]$. Furthermore, this kind of experiential learning encourages physical therapists to be lifelong learners [19] and to adapt their knowledge to changing care demands [20-23].

In light of the evidence, it seems important to create and facilitate in situ experience outside the university for Physical Therapy students to develop clinical expertise $[24,25]$ because it promotes situated learning [26-28]. In addition, this type of learning can enhance career development [29-31]. Experiential practice education promotes main areas of the physical therapists' formation such as: application of skills to the clinical context [32,33] improved confidence and clinical reasoning [34,35].

The aim of this study is to describe the professional and personal development of Physiotherapy Program students after participating in SACP as a service-learning course in their educational curriculum deepens undergraduates' and teachers' perceptions.

\section{Materials and Methods}

\subsection{Design}

Qualitative research methods with a grounded theory approach were used [36]. This study reports on students' and professors' perceptions during and after participating in SACP in the Grade of Physical Therapy [37,38]. Data collection was concurrent with the study reported and this contributed to an inductive research process [24].

Twenty students who had been doing the SACP and one professor who teaches these activities were identified for participation in the study. Purposive sampling was used to select five men and fifteen women students and teacher from SACP of 2011-2012 course. The mean age of the students was 22.6 years ( $\mathrm{SD} \pm 2.81$, range 21-29). The professor had ten years of experience teaching at university 
and five years' experience teaching SACP. Purposive sampling identified the participants to ensure they were typical of the phenomenon being studied [39,40]. All participants, twenty students and the professor, voluntarily agreed to participate and gave informed consent.

\subsection{Data Collection}

Four data collection tools were used. Each student completed a written diary after each session. There were eight sessions along the academic course and ten students participated in each educational session, so eighty written student diaries were collected.

Face-to-face audio-recorded semi-structured interviews were done (Table 1). Five motivated students and a professional teacher of SACP were interview two times. Because one of the SACP teachers was a main researcher, there was a prior relationship between the researcher and students and the professional teacher, so that the participants felt comfortable and could be honest about their reflections and responses. The first round of interviews took place before SACP started in the academic course. The second round of interviews was done after their participation in SACP. A total of twelve face-to-face interviews (ten with the students and two with the teacher) were recorded.

Table 1. Interview agenda.

\begin{tabular}{ccc}
\hline Interview & Date & Interview Agenda \\
\hline Initial Interview & January 2012 & Initial expectation; initial motivation; initial program knowledge \\
\hline Final Interview & June-July 2012 & Achieve of expectation; final experience; final learning \\
\hline
\end{tabular}

Internal and external observations were done [41]. The professor and a physical therapy teacher who does not teach in SACP filled out a structured field note after each educational session so that sixteen structured field notes were compiled.

Data from diaries, interviews, as well as internal and external observations were triangulated. The knowledge gleaned over four years of SACP was considered data as observational memory to contextualize, and contributed to the data analysis. Ethical approval was gained from the Research Unit of the Penitentiary Center. The project was approved by the Spanish General Secretariat of Penitentiary Institutions review board 1632-20/07/2012.

\subsection{Data Analysis}

Initially, the process of analysis involved transcripts of the structured field notes and students diaries. The first data analysis step was data immersion. The thematic analysis was guided by the systematic approach of Grounded Theory [42]. The analysis was done through a series of coding: open, axial and selective, and the constant comparative method [42] contributing to the creating conceptual and analytical framework. This analysis approach was used to try to explain the personal and professional development in the Physical Therapy program through the SACP.

Data were managed and organized using Atlas.ti, version 5.2 (ATLAS.ti Scientific Software Development $\mathrm{GmbH}$, Berlin, Germany), a qualitative software package version. This software facilitated the interactive process of grounded theory [43]. Interview passages, field notes and diary quotations were coded and subjected to comparison and differentiation. Similar concepts were clustered to form categories [44]. Final coding involved the interrelation categories and theory building thorough a network. The conceptual framework is presented and explained in the findings.

\subsection{Trustworthiness}

Participants' bias was controlled by an honest and trusting research-participant relationship that was established over a period of three years [45]. The researchers and participants had a shared knowledge of the SACP and therefore, this could be considered as insider research [46]. The absence of 
researcher bias was ensured by a constant verification and triangulation of the data from students' diaries, students' interviews, the professor's interviews, and the internal and external observations.

\section{Results}

Data from students' diaries, students' interviews, professor's interviews, internal and external observations were analyzed and showed good agreement with most components of the constructs and order of importance (Table 2). Students', teachers' and external observations supported the importance of applying knowledge and creating workplace practice.

Table 2. Triangulation of data.

\begin{tabular}{cccccc}
\hline $\begin{array}{c}\text { Component of the } \\
\text { Construct }\end{array}$ & $\begin{array}{c}\text { Students' } \\
\text { Diaries }\end{array}$ & $\begin{array}{c}\text { Students' } \\
\text { Interviews }\end{array}$ & $\begin{array}{c}\text { Professor' }^{\prime} \\
\text { Interview }\end{array}$ & $\begin{array}{c}\text { Internal } \\
\text { Observation }\end{array}$ & $\begin{array}{c}\text { External } \\
\text { Observation }\end{array}$ \\
\hline Apply Knowledge & $\mathrm{X}$ & $\mathrm{X}$ & $\mathrm{X}$ & $\mathrm{X}$ & $\mathrm{X}$ \\
Workplace Practice & $\mathrm{X}$ & $\mathrm{X}$ & $\mathrm{X}$ & $\mathrm{X}$ & $\mathrm{X}$ \\
Communication & $\mathrm{X}$ & $\mathrm{X}$ & $\mathrm{X}$ & $\mathrm{X}$ & No adapted \\
Assist People & $\mathrm{X}$ & $\mathrm{X}$ & $\mathrm{X}$ & $\mathrm{X}$ & $\mathrm{X}$ \\
Professional Skill & $\mathrm{X}$ & $\mathrm{X}$ & $\mathrm{X}$ & $\mathrm{X}$ & $\mathrm{X}$ \\
\hline
\end{tabular}

Five categories of professional and personal physical therapist development were generated from the data. The text and information in Figure 1 explain how the concepts are linked and describe their properties and dimensions according to the conceptual density required in grounded theory studies.

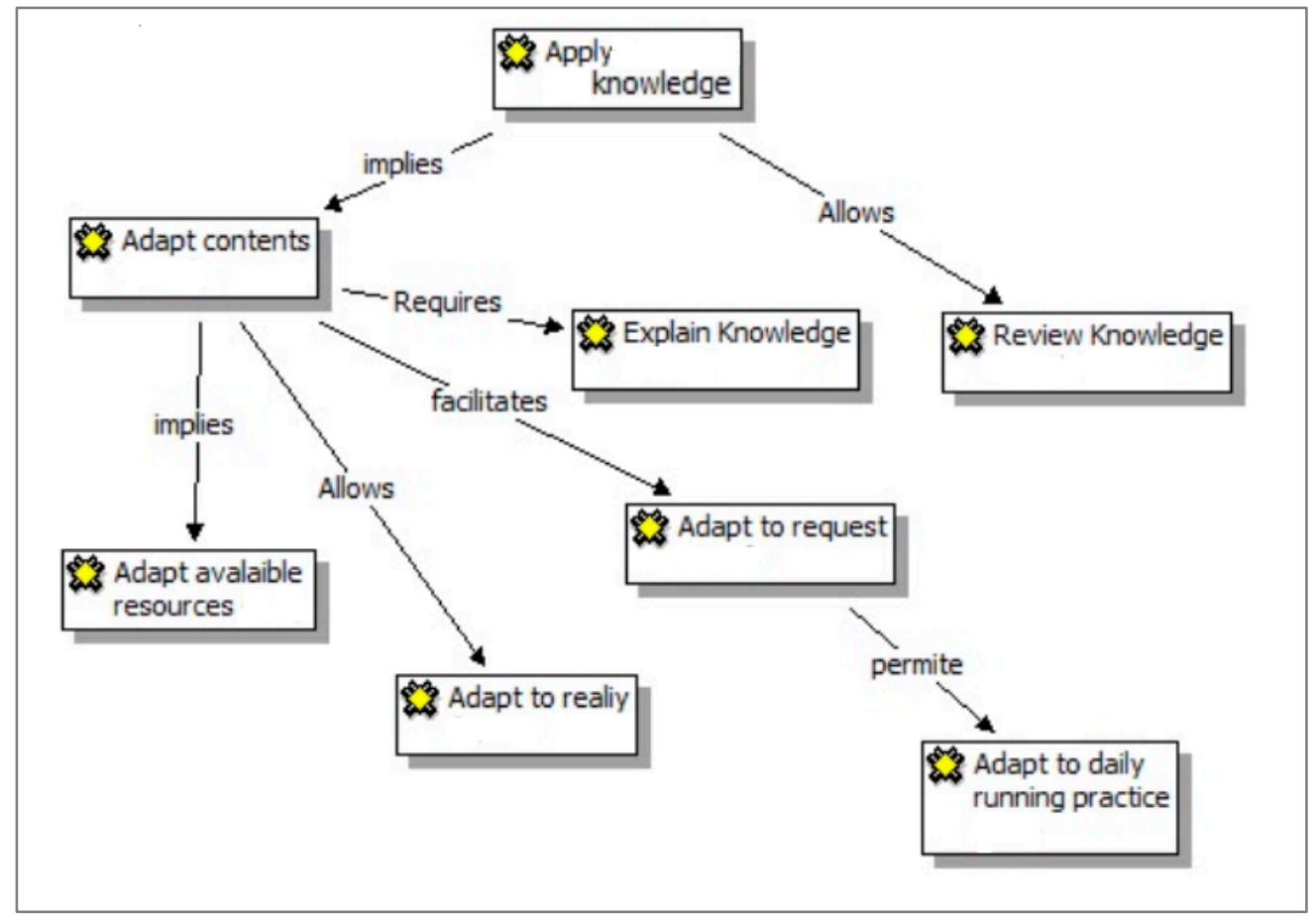

Figure 1. Create workplace practices.

Findings include quotations from participants presented in italics with names omitted to ensure participants' confidentiality. To provide trustworthiness, quotations are included to collect participants' experience. Quotations are referenced with a code that identifies its place within the analyzed document; for example, ISI1, 24 means that the quote is from the Initial Student Interview of student 1 and is in the 24th min of the audio. 


\subsection{Applying Knowledge}

A primary finding, supported by previous literature, was the importance of applying knowledge $[13,14]$. Several concepts are related to this category: reviewing knowledge and adapting knowledge to reality and available resources. Some students appreciate the satisfaction after having the opportunity of applying their learned knowledge, as cited below (Figure 1):

"The opportunity of a lot of things, review, deepen and apply to practice, a lot of things." (ISI3, 3)

"It is something that you have to review to apply, understand it and explain it, and this helps you to make this more automatic." (FSI1, 9)

Furthermore, the teacher emphasizes that student participation in the SACP provides the opportunity to review, apply and adapt knowledge:

"I think that it is very interesting that an unexpected event in the practice with prisoners appears, because it is a good opportunity for students to learn and adapt them-selves to changes." (SFN1, 88)

"It forces them to make an effort to adapt something that they know to concrete situations and in that situation they have to create rather than be given each step." (FTI1, 15)

\subsection{Create Workplace Practise}

The second identified theme was the importance of creating workplace practice for students. This category is related to other concepts such as appreciating multicultural differences, treating different people, open-mindedness, interest and situated learning.

"All the mates have gained in flying hours, in experience, in being able to face new things." (FSI4, 15)

"I noticed what the physical therapist reality outside the classroom is, because beyond the techniques there are other situations that we have to manage." (FSI2, 19)

"You have a more open mind to different situations and people that are in some kind of inequality." (ISI5, 2)

"This practice allows us to know a little of the unknown reality beyond our comfortable lifestyle." $(\mathrm{SD} 4,22)$

Creating workplace practice was considered to be an essential element of the educational development for students. Students and teachers recognize the important relationship between procedural knowledge needed for treating patients and theoretical knowledge gained during the formal university process, therefore, they relished the opportunity to treat patients in a workplace practice setting such as collaborating with a prisoner reinsertion program with a special population.

"For students, it is a big help to practice with people for their future professional development." (SFN1, 28)

"Students can treat a minority group in a reinsertion centre with physiotherapy sport techniques." (ITI1, 10)

"It is a big help to face real patients." (SD5, 38)

\subsection{Communication}

Communication is another central theme found in the results. Communication with the patient, with the family and with the team is a necessary skill for an effective physical therapy intervention. Communication is a bidirectional process; the physical therapist needs to gain information and also to provide information to those involved in the patient's intervention [47]. 
"In this kind of sessions, we can improve our confidence and consolidate our knowledge, not only in an academic level in the physiotherapy framework but in facts such as expression and communication." $(\mathrm{SD6}, 402)$

For physical therapists, it is important to be able to interpret the lay speech of the patient and then to give adapted explanations to the patients' understanding [47]. Students have been able to experience the importance of a fluent communication with the patient to meet the patient's particular and special needs as a prisoner in a reinsertion program.

"We do not only make things relate to physiotherapy, but also with personal communication. Besides you lose all your prejudices." (SD6, 234)

"Physical contact, between students and inmates in physiotherapy techniques is really positive to facilitate communication." (SFN2, 7)

\subsection{Helping People}

Assisting people is a final theme that emerges from the data. It is not a primary finding but it is at the end of the entire process. Because this is the ultimate result, this helps students to feel satisfaction and they feel themselves being a useful person.

"You feel yourself useful; you help people that in other circumstances would not have this help, my expectations have been overcome." (FSI1, 34)

"Solidarity Activities allow students to see another kind of reality, to become more sensitive, to understand their profession as a way to help others; this is for me the biggest satisfaction." (FTI1, 2)

"It is very rewarding to see how your ideas and knowledge learnt during years is beneficial for the others." (SD6, 44)

"We have helped people, to improve their health and their quality of life." (SD5, 40)

\subsection{Professional Skill}

The last category found was the importance of developing professional skill as an important aspect of being an efficient professional. Professional skill, also called expertise or ability, is a quality that has to be attained. At the time that students start their career and participate in this type of service learning, they gain extra practical time.

"Some students have pleasantly surprised me; because I have seen really good management with the group." (FTI1, 26)

"Students have to manage uncertainty and to make decisions to adapt themselves to the reality." (SFN1-88)

Skill is closely related to self-confidence and security. Participants enhance the opportunity thorough this SACP to develop their skill in a real workplace practice with a special population.

"You improve your confidence, you manage better with them. I have seen a progression in me." $(\mathrm{FSI} 5,2)$

"We have successfully managed in a new situation for us." (SD9, 60)

"The session has been very rewarding as much on a professional level as a personal level and it has helped me enhance my self-confidence." (SD8, 248) 


\section{Discussion}

It is well known that the use of workplace practice in different contexts and environments provides more active teaching and learning methodologies [48]. Based on Bandura's Social Learning Theory [49], modelling examples allows students to learn by observing a model perform a task and then learn by doing. Several studies include the importance of learning from examples adapted to the prior students' experience [50,51]. For novice students, instructions are more effective than problem solving; for advanced students, it is the opposite, because they have prior knowledge of the task and have acquired a schema for solving a problem [52]. Therefore, advanced students benefit from practice.

Experiential learning can be organized in widely different environments. This can contribute to physical therapy students' development. One essential skill for the healthcare professional is the understanding of culturally diverse classes of people [53,54]. Cultural competence is the combination of cultural awareness, cultural knowledge and cultural sensitivity [55]. Physical therapists need to practice with culturally diverse groups to develop this competence and therefore, educational curricula for physical therapists should offer this opportunity. Working with inmates has been a good initiative to work on cultural sensitivity and has helped students to lose their prejudices.

The five themes found supports previous evidence about professional and personal development of physical therapy students. The findings complement other recent research on translational learning and clinical expertise in Physical Therapy [4,56,57].

Themes and resulting theory were generated from data derived directly from students' and teachers' experience. Research findings suggest that SACP intervention promotes the application of knowledge and the creation of workplace practice that facilitates student development as lifelong learners and also improves motivation for learning. These results are similar to findings from several previous studies $[17,18]$.

Taking part in the course SACP during educational studies helps students to experience a challenge. It is important for them to face this challenge, manage it and solve problems that arise in the situation. As other studies have shown $[17,18,42]$, it is important to include the workplace practice in professional education courses as a central aim for students' education. In this workplace practice, a real-life situation is when students really have to use all their skills to achieve a successful patient intervention.

Managing uncertainly also enhances students' self-confidence and facilitates clinical reasoning. As Davis and Burnand's (1992) research found, to generate doubt is closely related to spiral learning, in which a student can return to another level of practice or study. Knowledge and experience are not simply piled but are integrated and promote a much deeper and specialized level of knowledge and skills [58].

In contrast with previous studies [59], in which students doubt their ability to apply theory to practice, it was found with this research that there is good agreement between this term of 'ability' and its importance for physical therapy students' development.

On the other hand, no agreement was found between the students' ability to adapt their communication level to the patients' characteristics [57]. In contrast with previous studies regarding postgraduate students, where a high level of communication with the patients was discovered, in this study a discrepancy was found. While students feel an improvement in their communicative skills, teachers and external observation do not agree and, in actuality, they think that students need even more workplace practice with special populations to develop this skill.

More attention has to be focused on reflecting on the understanding of the importance of communication and new methodological strategies could be introduced in the next courses to pay more attention to the development of this particular skill, with specific practice activities. In addition, this discrepancy could have occurred because this intervention was done with undergraduate students and the research cited was with postgraduate and, therefore, older, more experienced students.

Furthermore, the results support that students who take this course improved their special technical skills, as was found in previous studies [24,25,33]. This finding demonstrates an improvement 
in clinical expertise development after completing SACP, related with the opportunity for the students to gain practice and apply adapted knowledge in different environments and populations.

Finally, there was a high level of satisfaction [60] and motivation among student participants after helping people with special characteristics and needs. All participants expressed deep happiness after taking SACP. This, in fact, is good for their mental health and facilitates interest and motivation among students [60,61], two main characteristics of lifelong learners [62].

\section{Limitations}

It is important to note that the final theory of professional and personal physical therapist development through SACP was developed from students' and teachers' perceptions. A further limitation was that it was carried out only with students of SACP. The research results were obtained from data co-created with participants, and as such are caught in a specific time and place. Although findings cannot be automatically generalized, they could be transferrable to other similar situations.

\section{Conclusions}

The research results suggest that the intervention, namely SACP, promotes the application of knowledge, the creation of workplace practice, and promotes the development of physical therapy students as lifelong learners, and improves motivation for learning. The findings of this study add to the growing body of evidence about the importance of situated learning and knowledge application in real clinical contexts. The participants gained in improving communication and enhancing their own self-confidence. The students increased their interest in learning and attained a deep feeling of satisfaction.

As such, these findings could provide some insight into meeting the needs of Physical Therapy education to promote students' professional and personal development. It would be appropriate to continue this work further by exploring similar situations to enable analytic generalization.

\section{Lessons for Practice}

One of the special workplace settings where physical therapy students could develop their practical and communicative skills with culturally diverse classes of people is a prison. This kind of experiential learning prepares students to construct and implement a successful patient intervention in different realities.

Although it is difficult to create the same workplace practice with a challenging population such as prisoners, it would be recommended for Physical Therapy degree programs to include workplace practice in different environments and with different populations to facilitate physical therapist development.

Author Contributions: Conceptualization, M.D.G.-R. and C.O.; Data curation, I.R.-C. and B.D.-P.; Formal analysis, I.R.-C. and M.D.G.-R.; Investigation, I.R.-C., V.A.-P. and B.D.-P.; Methodology, M.B.-M.; Project administration, M.D.G.-R.; Resources, B.D.-P.; Supervision, C.O.; Visualization, I.R.-C.; Writing-original draft, I.R.-C. and V.A.-P.; Writing-review and editing, J.-M.L.-M. and V.A.-P. All authors have read and agreed to the published version of the manuscript.

Funding: This research received no external funding.

Conflicts of Interest: The authors declare no conflict of interest.

\section{References}

1. Stew, G. Learning together in practice: A survey of interprofessional education in clinical settings in South-East England. J. Interprof. Care 2005, 19, 223-235. [CrossRef] [PubMed]

2. Mejia-Downs, A. An Intervention Enhances Resilience in Entry-Level Physical Therapy Students: A Preliminary Randomized Controlled Trial. J. Phys. Ther. Educ. 2020, 34, 2-11. [CrossRef] 
3. Frenk, J.; Chen, L.; Bhutta, Z.A.; Cohen, J.J.; Crisp, N.; Evans, T.; Fineberg, H.; Garcia, P.J.; Ke, Y.; Kelley, P.; et al. Health professionals for a new century: Transforming education to strengthen health systems in an interdependent world. Lancet 2010, 376, 1923-1958. [CrossRef]

4. Ajjawi, R.; Higgs, J. Core components of communication of clinical reasoning: A qualitative study with experienced Australian physiotherapists. Adv. Health Sci. Educ. 2011, 17, 107-119. [CrossRef]

5. Delany, C.; Bragge, P. A study of physiotherapy students' and clinical educators' perceptions of learning and teaching. Med. Teach. 2009, 31, 402-411. [CrossRef]

6. Malcolm, D.; Scott, A. Professional relations in sport healthcare: Workplace responses to organisational change. Soc. Sci. Med. 2011, 72, 513-520. [CrossRef]

7. Hogg-Johnson, S.; Cole, D.C.; Lee, H.; Beaton, R.E.; Kennedy, C.; Subrata, P. Changes in Physiotherapy Utilization in One Workforce: Implications for Accessibility among Canadian Working-Age Adults. Health Policy Polit. Sante 2011, 6, e93-e108. [CrossRef]

8. Shyu, G.-S.; Lin, S.-J.; Fang, W.-T.; Cheng, B.-Y. How to Screen Suitable Service Improve Community Health Care Services by University Students in Taiwan. Int. J. Environ. Res. Public Health 2020, 17, 5402. [CrossRef]

9. Ruiz-Montero, P.J.; Chiva-Bartoll, O.; Salvador-García, C.; Martín-Moya, R.; Montero, R.; Bartoll, C.; García, S.; Moya, M. Service-Learning with College Students toward Health-Care of Older Adults: A Systematic Review. Int. J. Environ. Res. Public Health 2019, 16, 4497. [CrossRef]

10. Freeth, D.; Reeves, S.; Goreham, C.; Parker, P.; Haynes, S.; Pearson, S. 'Real life' clinical learning on an interprofessional training ward. Nurse Educ. Today 2001, 21, 366-372. [CrossRef]

11. Ryan, S.; Higgs, J. Teaching and Learning Clinical Reasoning. In Clinical Reasoning in the Health Profession, 3rd ed.; Elsevier: Amsterdam, The Netherlands, 2008; pp. 379-387.

12. Jelley, W.; Larocque, N.; Patterson, S. Intradisciplinary Clinical Education for Physiotherapists and Physiotherapist Assistants: A Pilot Study. Physiother. Can. 2010, 62, 75-80. [CrossRef] [PubMed]

13. Kilminster, S.M.; Jolly, B.C. Effective supervision in clinical practice settings: A literature review. Med. Educ. 2000, 34, 827-840. [CrossRef] [PubMed]

14. Bryant, P.; Hartley, S.; Coppola, W.; Berlin, A.; Modell, M.; Murray, E. Clinical exposure during clinical method attachments in general practice. Med. Educ. 2003, 37, 790-793. [CrossRef] [PubMed]

15. Spencer, J. ABC of learning and teaching in medicine. Br. Med. J. 2003, 326, 591-594. [CrossRef] [PubMed]

16. Urquhart, R.; Cornelissen, E.; Lal, S.; Colquhoun, H.; Klein, G.; Richmond, S.; Witteman, H.O. A Community of Practice for Knowledge Translation Trainees: An Innovative Approach for Learning and Collaboration. J. Contin. Educ. Health Prof. 2013, 33, 274-281. [CrossRef]

17. Kell, C.M.; Van Deursen, R. Student learning preferences reflect curricular change. Med. Teach. 2002, 24, 32-40. [CrossRef]

18. Griffiths, Y.; Ursick, K. Using active learning to shift habits of learning in health care education. Internet J. Appl. Health Sci. Pract. 2004, 2, 2.

19. Constantine, M. Bringing masters' level skills to the clinical setting: What is the experience like for graduates of the master of science in manual therapy programme? Physiother. Theory Pract. 2012, 28, 595-603. [CrossRef]

20. Rios, C. Practice Knowledge and Expertise in the Health Professions. Pediatr. Phys. Ther. 2002, 14, 117-118. [CrossRef]

21. Higgs, J.; Andresen, L.; Fish, D. Practice Knowledge-Its Nature, Sources and Contexts. In Developing Practice Knowledge; Butterworth Heinemann: Edinburgh, UK, 2004; pp. 51-70.

22. Higgs, J.; Aijawi, R.; Smith, M. Working and Learning in Communities of Practice. In Contexts of Physiotherapy Practice; Churchill Livingstone: Sydney, Australia, 2008.

23. Bartlett, D.J.; Lucy, S.D.; Bisbee, L.; Conti-Becker, A. Understanding the Professional Socialization of Canadian Physical Therapy Students: A Qualitative Investigation. Physiother. Can. 2009, 61, 15-25. [CrossRef]

24. Rushton, A.; Lindsay, G. Defining the construct of masters level clinical practice in manipulative physiotherapy. Man. Ther. 2010, 15, 93-99. [CrossRef] [PubMed]

25. Petty, N.J.; Scholes, J.; Ellis, L. The impact of a musculoskeletal masters course: Developing clinical expertise. Man. Ther. 2011, 16, 590-595. [CrossRef] [PubMed]

26. Allan, J.; O’Meara, P.; Pope, R.; Higgs, J.; Kent, J.; Pope, R. The role of context in establishing university clinics. Health Soc. Care Community 2010, 19, 217-224. [CrossRef] [PubMed]

27. Fish, D. Appreciating Practice in the Caring Professions; Butterworth Heinemann: Oxford, UK, 1998. 
28. Billett, S. Workplace participatory practices, conceptualising workplaces as learning environments. J. Workplace Learn. 2004, 16, 321-324. [CrossRef]

29. Dall'Alba, G.; Sandberg, J. Unveiling Professional Development: A Critical Review of Stage Models. Rev. Educ. Res. 2006, 76, 383-412. [CrossRef]

30. Evans, C.; Yeung, E.; Markoulakis, R.; Guilcher, S. An Online Community of Practice to Support Evidence-Based Physiotherapy Practice in Manual Therapy. J. Contin. Educ. Health Prof. 2014, 34, 215-223. [CrossRef]

31. Stathopoulos, I.; Harrison, K. Study at Master's Level by Practising Physiotherapists. Physiotherapy 2003, 89, 158-169. [CrossRef]

32. Conneeley, A.L. Study at Master's Level: A Qualitative Study Exploring the Experience of Students. Br. J. Occup. Ther. 2005, 68, 104-109. [CrossRef]

33. Green, A.; Perry, J.; Harrison, K. The influence of a postgraduate clinical master's qualification in manual therapy on the careers of physiotherapists in the United Kingdom. Man. Ther. 2008, 13, 139-147. [CrossRef]

34. Morris, J.; Leonard, R. Physiotherapy students' experiences of palliative care placements-Promoting interprofessional learning and patient-centred approaches. J. Interprof. Care 2007, 21, 569-571. [CrossRef]

35. Grant, A. The use of qualitative research methodologies within musculoskeletal physiotherapy practice. Man. Ther. 2005, 10, 1-3. [CrossRef] [PubMed]

36. Masley, P.M.; Havrilko, C.-L.; Mahnensmith, M.R.; Aubert, M.; Jette, D.U. Physical Therapist Practice in the Acute Care Setting: A Qualitative Study. Phys. Ther. 2011, 91, 906-919. [CrossRef] [PubMed]

37. Denzin, N.; Lincoln, Y. Handbook of Qualitative Research; Sage: Newbury Park, UK, 1994.

38. Lincoln, Y.; Guba, E. Naturalistic Inquiry; Sage: Newbury Park, UK, 1985.

39. Charmaz, C. Constructing Grounded Theory: A Practical Guide through Qualitative Analysis; Sage: London, UK, 2006.

40. Keen, J.; Packwood, T. Using Case Studies in Health Services and Policy Research. In Qualitative Research in Health Care, 2nd ed.; British Medical Journal Publishing Group: London, UK, 2000; pp. 50-58.

41. Ozanne, J.L.; Strauss, A.; Corbin, J. Basics of Qualitative Research. J. Mark. Res. 1992, 29, 382. [CrossRef]

42. Mays, N.; Pope, C. Qualitative Research: Observational methods in health care settings. BMJ 1995, 311, 182-184. [CrossRef]

43. Bringer, J.D.; Johnston, L.H.; Brackenridge, C. Using Computer-Assisted Qualitative Data Analysis Software to Develop a Grounded Theory Project. Field Methods 2006, 18, 245-266. [CrossRef]

44. Annells, M. Grounded Theory. In Nursing Research: Methods, Critical Appraisaland Utilisation, 2nd ed.; Mosby: Sydney, Australia, 2003; p. 172.

45. Mercer, J. The challenges of insider research in educational institutions: Wielding a double-edged sword and resolving delicate dilemmas. Oxf. Rev. Educ. 2007, 33, 1-17. [CrossRef]

46. Robson, C. Real World Research, 2nd ed.; Blackwell: Hoboken, NJ, USA, 2002.

47. Kidd, M.O.; Bond, C.H.; Bell, M.L. Patients' perspectives of patient-centredness as important in musculoskeletal physiotherapy interactions: A qualitative study. Physiotherapy 2011, 97, 154-162. [CrossRef]

48. Boekhout, P.; Gog, T.; Van De Wiel, M.W.J.; Geraets, J.; Gerards-Last, D. Example-based learning: Effects of model expertise in relation to student expertise. Br. J. Educ. Psychol. 2010, 80, 557-566. [CrossRef]

49. Bandura, A. Social Learning Theory; Prentice-Hall: Englewood Cliffs, NJ, USA, 1977.

50. Kalyuga, S. Expertise Reversal Effect and Its Implications for Learner-Tailored Instruction. Educ. Psychol. Rev. 2007, 19, 509-539. [CrossRef]

51. Kalyuga, S.; Chandler, P.; Tiovinen, J.; Sweller, J. When problem solving is superior to studying worked examples. J. Educ. Psychol. 2001, 93, 579-588. [CrossRef]

52. Kalyuga, S.; Ayres, P.; Chandler, P.; Sweller, J. The expertise reversal effect. Educ. Psychol. 2003, $38,23$. [CrossRef]

53. Bialocerkowski, A.E.; Wells, C.; Grimmer, K. Teaching physiotherapy skills in culturally-diverse classes. BMC Med. Educ. 2011, 11, 34. [CrossRef] [PubMed]

54. Lewis, A.N.; Bethea, J.; Hurley, J. Integrating cultural competency in rehabilitation curricula in the new millennium: Keeping it simple. Disabil. Rehabil. 2009, 31, 1161-1169. [CrossRef] [PubMed]

55. Papadopoulos, I.; Tilki, M.; Taylor, G. Transcultural Care: A Guide for Health Care Professionals; Quay Books: Limerick, Ireland, 1998. 
56. Davies, K.; Harrison, K.; Clouder, D.; Gilchrist, M.; McFarland, L.; Earland, J. Making the transition from physiotherapy student to interprofessional team member. Physiotherapy 2011, 97, 139-144. [CrossRef] [PubMed]

57. Higgs, J. A programme for developing clinical reasoning skills in graduate physiotherapists. Med. Teach. 1993, 15, 195-205. [CrossRef]

58. Davis, B.D.; Burnard, P. Academic levels in nursing. J. Adv. Nurs. 1992, 17, 1395-1400. [CrossRef]

59. Telfer, J. Explicating Expectations of Faculty and Students in the Professional Education of Physiotherapy. Ph.D. Thesis, University of Toronto, Toronto, ON, Canada, 1997.

60. Sam, D.L. Satisfaction with life among international students: An exploratory study. Soc. Indic. Res. 2001, 53, 315-337. [CrossRef]

61. Henning, M.A.; Hawken, S.J.; Bharatharaj, J.; Zhao, Y.; Doherty, I. Asian medical students: Quality of life and motivation to learn. Asia Pac. Educ. Rev. 2011, 12, 437-445. [CrossRef]

62. Higgs, J.; Refshauge, K.; Ellis, E. Portrait of the physiotherapy profession. J. Interprof. Care 2001, 15, 79-89.

Publisher's Note: MDPI stays neutral with regard to jurisdictional claims in published maps and institutional affiliations.

(C) 2020 by the authors. Licensee MDPI, Basel, Switzerland. This article is an open access article distributed under the terms and conditions of the Creative Commons Attribution (CC BY) license (http://creativecommons.org/licenses/by/4.0/). 